\title{
SECTION 5 OF THE CLAYTON ACT AND THE NOLO CONTENDERE PLEA
}

In order to insure the effectiveness of the Sherman Act, ${ }^{1}$ Congress assigned an important policing role to private parties; persons ${ }^{2}$ injured by an antitrust violation were allowed to bring an action for treble damages against the offender. As originally conceived, private enforcement was intended to operate independently of Government prosecution. ${ }^{3}$ But by 1914 Congress recognized that the private litigant could not perform his function without assistance. In that year Congress attempted to strengthen the private enforcement scheme by enacting

1. 26 Stat. 209 (1890), as amended, 15 U.S.C. $\$ \S 1-7$ (1964).

2. The "persons" authorized to invoke the treble damage action provision included corporations and associations existing under the laws of the United States, of any state or territory, or of any foreign country. This has been held to encompass municipalities, Chattanooga Foundry \&: Pipe Works v. City of Atlanta, 203 U.S. 390 (1900), and states, Georgia v. Evans, 316 U.S. 159 (1942). But the United States was cxcluded as a beneficiary of the treble damage action. United States v. Cooper, 312 U.S. 600 (1941). In 1955 Congress added section $4 \mathrm{~A}$ to the Clayton Act to permit the United States the additional remedy of a private action, but only for actual damages. 69 Stat. 282 (1955), 15 U.S.C. $\$ 15 a$ (1964). The purposes and effects of the treble recover are discussed in Micconnell, The Treble Damage Action, 1950 U. ILL. L.F. 659; Vold, Are Threcfold Damages Under the Antitrust Act Penal or Compensatory? $28 \mathrm{Kr}$. L.J. 117 (1910).

3. See Statement of Walton Hamilton, Hearings on H.R. 7905 Before the Subcommittee on the Study of Monopoly Power of the House Committee on the Judiciary, 81st Cong., 2d Sess., 56 (1950).

4. See 51 Conc. Rec. 13,851 (1914) (remarks of Senator Walsh): "We all know that the private individual is always at a disadvantage. He is never armed with the means at his command to cope with these great organizations; and that was the very reason why this act was passed - ..." See id. at 15,825 (remarks of Senator Reed); id. at 16,046 (remarks of Senator Norris). The first twenty-five years of the Sherman Act produced only forty-six private actions, of which plaintiffs were successful in only four. A D. Neale, TuE A.rs?tRUST LAws of the UNITEd States of America 389 (1960). Undoubtedly the private litigants' lack of success during this period may be in part attributable to the general unfamiliarity in the legal community with the meaning of the new law. But equally significant was the fact that private suitors were not equipped with the tools to promote independent antitrust enforcement. One of the most essential ingredients of law enforcement is the power to detect and investigate possible infractions and then to apprehend the wrongdoers. The private litigant, however, without the services of a grand jury and without the powers of subpoena or discovery, was helpless to conduct any meaningful inquin. And the treble damage action furnished to him by Congress was not useful for that purpose. That remedy, by itself, was hardly an enforcement tool in this sense; it was no more than a potential for inflicting severe punishment once the offender was detected and apprehended. For a picturesque account of the formidable burden of private litigants prior to 1914 see W. Hamilton \& I. TIll, ANTTRust in ACTion, 82-83 (TNEC MIonograph No. 16, 1940). 
Section 5 of the Clayton Act, 5 which allowed private suitors to introduce as prima facie evidence of violation the judgments entered in prior Government proceedings against the same defendants for the same offense. However, Congress added a proviso making Section 5 inapplicable to "consent judgments or decrees entered before any testimony has been taken." antitrust defendants revived the nolo contendere plea. ${ }^{7}$ That plea has since become a standard fixture in criminal antitrust cases, and its value to defendants is incalculable.

Since a case disposed of on a nolo plea will involve a trial only on the issue of punishment, the plea relieves a defendant of the great burden in time, expense, ${ }^{8}$ and personal inconvenience involved in making a full defense. The plea, furthermore, is attractive to defendants because it "does not normally carry with it in the courts or in

5. 38 Stat. 731 (1914), as amended 15 U.S.C. $\S 16$ (a) (1964). The text of Section 5 as originally enacted read, in part:

That a final judgment or decree hereafter rendered in any criminal prosccution or in any suit or proceeding in equity brought by or on behalf of the United States under the antitrust laws to the effect that a defendant has violated said laws shall be prima facie evidence against such defendant in any suit or proceeding brought by any other party against such defendant under said laws as to all matters respect. ing which said judgment or decree would be an estoppel between the partics thercto: Provided, this section shall not apply to consent judgments or decrees entered bcfore any testimony has been taken."

The section was amended in 1955 to permit the United States to introduce its own prior judgments as prima facie evidence in its own private damage actions under the newly enacted Section 4A of the Clayton Act. 69 Stat. 282 (1955), 15 U.S.C. $\S 16(a)$ (1964).

6. 38 Stat. 731 (1914), as amended 15 U.S.C. $\$ 16$ (a) (1964).

7. For discussion on the history and characteristics of the nolo contenderc plea sce Lenvin \& Myers, Nolo Contendere: Its Nature and Implications, 51 YALE L.J. 1255 (1942); Comment, Nolo Contendere-Its Use and Effect, 52 CALIF. L. REv. 408 (1964). Sce also Hudson v. United States, 272 U.S. 451 (1926). Because nolo contendere is but an "impliced confession," it establishes the fact of guilt solely for the purpose of the particular case in which it is tendered and accepted. Accordingly, in a subsequent civil action prcdicated upon the same set of facts to which the defendant pleaded nolo in the criminal procecd. ing the plea will not be admissible against the defendant as an evidentiary admission to prove those facts, and the defendant will not be estopped from denying them. It is this feature of the nolo plea that distinguishes it from the plea of guilty, and accounts for the difference of treatment accorded to the two pleas for the purpose of $\S 5$.

8. The costs of defense is one of the primary concerns of the antitrust defendant. In fact, one commentator remarked: "Many defendants will enter into a consent decrec and plead nolo contendere even though in their minds and hearts they are satisfied that they have never violated the antitrust laws. The pressure there is the avoidance of an expensive or a lengthy trial." See Testimony of Milton Handler, Hearings on H.R. 7095 Before the Subcommittee on the Study of Monopoly Power of the House Committec on the Judiciary, 81st Cong., 2d Sess., 6 (1950). 
the public mind the same stigma of knowing guilt and moral turpitude as does the plea or conviction of guilty." 3 Defendants plead nolo to avoid adverse publicity, and for this reason the plea is useful even when the possibility of subsequent private actions is limited.10 The primary value of the nolo contendere plea to the antitrust defendant, however, is that a judgment entered upon its acceptance is a "consent

9. Memorandum of the Government in Opposition to the Acceptance of Pleas of Nolo Contendere 4-5, I Antitrust Pleading File, United States v. Westinghouse Co., Cr. 20234 (E.D. Pa.) (The Antitrust Division Pleading File, cited hercinafter as Antitust Pleading File, is located in the Department of Justice, Washington, D.C.).

It may be, and often is, instead characterized as a "compromise" betwcen the defendants and the Government, or as a confession of technical guilt under circumstances where the violation of the law involved results from an honest disagreement as to the proper scope of the law rather than as a conscious and knowing attempt to violate the criminal laws of the United States.

Ibid.

Part of the desire of the antitrust defendant to aroid the stigma of criminal conviction is the belief that the offense committed, being of an cconomic nature, is necessarily less reprehensible and should entitle the wrongdoer to special consideration. One defense attorney, pressing for acceptance of a nolo plea, reflected this attitude:

[T]hese acts involved in these indictments are said to be violations of these regulatory measures that deal with the economy of the country. . . [W] are not con. cerned ... with crimes of violence ... or other serious crimes against the Government; we are dealing here with crimes having to do with the regulation of the economy. ...

United States v. Westinghouse Corp., 1960 Trade Cas. 76753, 76755 (E.D. Pa.). This notion was strongly rejected by Judge Weinfeld in United States v. Standard Ultramarine \& Color Co., 137 F. Supp. 167, 170 (S.D.N.Y. 1955):

The concept that antitrust violations really are "minor" and "tcchnical" infractions, involve no wrongdoing, and merely constitute "white collar" offenses, has no place in the administration of justice.

A conviction upon a nolo plea may, however, have some minor undesirable consequences. In some jurisdictions it is not treated differently from any other conviction. Hence the nolo conviction could make the defendant a multiple offender for the purposes of collateral proceedings. And the plea may be admissible in subsequent litigation for the purpose of impeaching the witness. Pfotzer v. Aqua Systems, Inc., 162 F.2d 779, 785 (2d Cir. 1947). See generally, Lenvin \&: Myers, Nolo Contendere: Its Nature and Implications, supra note 7.

10. In one unusual case, United States v. American Oil Co., 65 Cr. 150(3) (E.D. Mo. 1965), for example, eighteen defendant oil companies pleaded nolo contendere to charges of price fixing and bid rigging in connection with certain contracts with the State of Missouri. The state was the only party subject to injury by the alloged violation and therefore the only party which could have sued for treble damages. However, prior to the entry of their plea the defendants effectively insulated themselves from exposure to treble damages by mysteriously volunteering to the state approximately $\$ 2$ million in "damages" and obtaining in return a covenant not to sue. Subsequently the corporate officials issued numerous public statements alleging ignorance of any activities constituting antitrust violations. Government's Brief, Antitrust Pleading File, United States v. American Oil Co., 65 Cr. 150(3) (E.D. Mo. 1965). 
judgment" within the proviso to Section 5 and therefore cannot be used as prima facie evidence of guilt in subsequent private actions. ${ }^{11}$

Whether the antitrust defendant will enjoy these advantages in a given case depends, in theory at least, upon the exercise of discretion by the courts under Rule 11 of the Federal Rules of Criminal Pro. cedure, ${ }^{12}$ which provides that a defendant may plead nolo contendere "with consent of the court." 13 In practice, the Government's position regarding the propriety of the nolo plea in individual cases has become an important and sometimes decisive criterion in the decision under Rule 11.

\section{The Government's Postition on Nolo Contendere Pleas}

Three possible positions seem available to the Government in establishing a consistent policy regarding nolo pleas. It could always acquiesce in or always oppose every attempt to plea nolo contendere. Or the Government could proceed on a case by case basis.

Prior to 1953 it was the practice of the Government not to oppose acceptance of nolo contendere pleas. And it was the practice of the courts to allow the plea as a matter of course. In that year the Attorney General, observing that "uncontrolled use of the plea has led to shockingly low sentences and insignificant fines which are no deterrent to crime," 14 initiated the policy of opposing the plea except "in the most unusual circumstances."15

11. The question was first raised and settled in Twin Ports Oil Co. v. Pure Oll Co., 26 F. Supp. 366 (D. Minn. 1939), aff'd, 119 F.2d 747 (8th Cir. 1941), cert. denied, 314 U.S. 644 (1941). There it had been urged that "a consent judgment in a criminal casc is an anomaly in legal parlance." 26 F. Supp, at 371. The court conceded that "strictly spcak. ing" the phenomenon of a consent judgment in a criminal proceeding may not exist, but, upon an examination of the legislative history and purpose of the proviso, responded:

If Congress intended to designate judgments entered on pleas of guilty or nolo contendere, before any testimony had been taken, as consent judgments, this Court must give effect to such intention, however unusual or inappropriate the expression may be. Ibid. See also General Elec. Co. v. City of San Antonio, 334 F.2 480 (5th Cir, 1964); City of Burbank v. General Elec. Co., 329 F.2d 825 (9th Cir. 1964); Commonwealth Edison Co. v. Allis-Chalmers Mfg. Co., 323 F.2d 412 (7th Cir. 1963), cert. denied, 376 U.S. 959 (1964).

12. 18 U.S.C., App. at 3748 (1964).

13. Ibid.

14. The Attorney General's position, set out in a memorandum to the United States Attorneys, is quoted in United States v. Jones, 119 F. Supp. 288, 289 n.l (S.D. Calif. 1954). It stated:

One of the factors which has tended to breed contempt for federal law enforcentent in recent times has been the practice of permitting as a matter of course in many criminal indictments the plea of nolo contendere. While it may serve a legitimate purpose in a few extraordinary situations ... I can see no justification for it in everyday practice, particularly where it is used to avoid certain indirect consequences of pleading guilty.... 
In reversing the former practice of acquiescence in all cases, the Government necessarily rejected an interpretation of the proviso to Section 5 under which the antitrust defendant would have an unqualified right to capitulate without trial. ${ }^{16}$ Such a construction of Section 5 attributes to Congress an intent to induce submission of defendants by imposing a penalty on those who insist on going to trial. The inducement is, on this reading of the statute, embodied in the proviso, and the penalty lies in the prima facie evidence provision in the body of Section 5. The "defendant's right" theory of Section 5, which would require the Government to acquiesce in every case, has been based, in part, on interpretations of legislative history. One Congressman, for example, offered this explanation of Section 5:

\footnotetext{
Uncontrolled use of the plea has led to shockingly low sentences and insignificant fines which are no deterrent to crime. As a practical matter it accomplishes little that is useful even where the Government has civil litigation pending. Morcover, a person permitted to plead nolo contendere admits guilt for the purpose of imposing punishment for his acts and yet, for all other purposes, and as far as the public is concerned, persists in his denial of wrongdoing. It is no wonder that the public regards consent to such a plea by the Government as an admission that it has only a technical case at most and that the whole proceeding was just a fiasco.

15. Id. at 290 . The change of policy was met by resistance in the courts. See, e.g. United States v. Jones, supra note 14 , at 290 , where the court responded to the Altorney General's memorandum:

While this may be an overall command from the head of an Exccutive Department to his subordinates, it does not purport to be, nor could it be, anything more. It is not binding upon the Court. . . E Even if the United States Attorney is forbidden to do so, the Court must exercise its discretion in each case. ... [A]nd in the absence of some reason why a defendant should not have the benefit of the plea, the Court will ordinarily allow it to be entered.

Some courts found it necessary to determine whether or not the Government's opposition was "seriously offered," or whether it was just implementing a general policy of opposition to nolo pleas. See, e.g., United States v. Rubber Mfrs. Ass'n, 1959 Trade Cas. 75.651 (S.D. N.Y.) (Court accepted the pleas, taking into account Government's general policy). To overcome the courts' resistance, the Government on occasions has had to make special attempts to impress upon the court the importance of denial of the nolo pleas. In United States v. Westinghouse Elec. Corp., 1960 Trade Cas. 76,753 (E.D. Pa.), for example, the Attorney General submitted an affdavit to the court in which he alleged that "these indictments charge as serious instances of bid-rigging and price-fixing as have been charged in the more than half-century life of the Sherman Act." Affidavit of William P. Rogers, the Attorney-General of the United States, in Opposition to Pleas of Nolo Contendere 2. I Antitrust Pleading File, United States v. Westinghouse Corp., Cr. 20234 (E.D. Pa. 1960). In addition, the Acting Assistant Attorney-General in change of the Antitrust Division appeared in person to present the Government's oral argument in opposition to the pleas. 1960 Trade Cas. 76,753-54.

16. The view that the proviso to Section 5 grants to the antitrust defendant an "unqualified right" to capitulate has been accepted by some courts. Sec, e.g., United States v. Brunswick-Balke-Collender Co., 203 F. Supp. 657 (E.D. Wis. 1962); United States v. Ward Baking Co., 1963 Trade Cas. 77499 (N.D. Fla.), vacated and remanded, 376 U.S. 327 (1964) (both cases involved civil consent decrees).
} 
If the Government brings a suit against a trust or monopoly and it surrenders, we eliminate the effect of the "prima facie" judgment. If it fights and loses, then the "prima facie" effect is given to the final judgment. ... ${ }^{17}$

This construction of Section 5 and the evidence adduced to support it may easily be dismissed. Although the proviso to Section $5 \mathrm{might}$ be seen as an inducement for defendants to capitulate, its primary concern was not with defendants' "rights" but rather with the added burden imposed on the Government by the body of Section 5 . The draftsmen apparently felt that the prima facie evidence provision would hinder the Government's effort to obtain relief without trial by making defendants unwilling to negotiate. The proviso was viewed as a way to ease the Government's enforcement burden and minimize expense. ${ }^{18}$ Although the proviso is an awkward attempt to achieve this end, it cannot be read to declare a right of every antitrust defendant to submit without trial. It is incongruous to say that a defendant has a right to save the Government time and money. The proviso merely says that a judgment shall not have prima facie effect if it is rendered before any testimony has been taken. Properly read, the proviso talks

17. 51 Cong. Rec. 16,276 (1914) (remarks of Representative Webb); see id. at 15,824 (remarks of Senator Lewis).

18. See, e.g., the views of Representative Graham on the original Section 5:

From the standpoint of the Government, the proposal to make Government decrees conclusive in private suits is open to serious objection. In various proceedings taken by the Government under the Sherman Act, parties have been persuaded to consent to decrees granting all the relief which the Government demanded. Such consent decrees have accomplished, without the consumption of the time and expense involved in conducting prosecutions, all the relief which could be obtained by successful litigation. No hindrance should be put in the way of the Department of Justice in respect of these negotiations.

If this proposal were enacted, it would deter any company from ever consenting to the entry of a decree in a Government suit under the antitrust laws; for such a decree would simply invite a flood of litigation that might bankrupt any company. [Emphasis added.]

H.R. REp. No. 627, 63d Cong., 2d Sess., pt. 2, at 9-10 (1914) (Minority Report). The original Section 5 contained a second proviso that exempted from the application of the prima facie evidence provision judgments entered in suits then pending in which the Government was negotiating for consent decrees. This proviso, according to one Senator, was

put in with a view to facilitating the Government to carry out consent matters which had been entered into in the form of settlement in equity proccedings wherein the defendant had possibly come into court and agreed upon a decree and thus relieved the Government of the necessity of taking evidence and the grent expense incident thereto. [Emphasis added.]

51 CoNG. Rec. 15,824 (1914) (remarks of Senator Lewis). See id. at 16,270 (remarks of Representative Webb). 
about what happens after a judgment has been entered; it gives to defendants an assurance that if their surrender is accepted the judgment entered will not be admissible against them as prima facie evidence in subsequent proceedings. If the proviso declares any right at all, it would belong to the Government, not to the defendant.

There is slight support for the "defendant's right" theory in the belief of some Congressmen that the phrase "consent judgments" in the proviso included judgments entered after guilty pleas. ${ }^{10}$ If the defendant can control the application of the proviso to this extent (surely the defendant has the "right" to plead guilty), then the "defendant's right" theory of nolo pleas cannot be rejected simply on the theory that Congress should not be taken as having given control of the proviso to defendants. But the members of Congress who read the proviso to include pleas of guilty appear to have been only those who opposed the entire proviso as being a concession to the monopolies and an abandonment of the principles of the Sherman Act. ${ }^{20}$ This tactic of exaggerating the meaning of a provision is often used by its opponents. In any event the legislative history shows that there was no consensus on the status of a guilty plea under the proviso. ${ }^{21}$

19. See, e.g., 51 Cong REc. 16,046 (1914) (remarks of Senator Norris): "The real effect of that proviso is to make the section inapplicable to cases in which consent judgments have been taken in cases where pleas of guilty have been entered by the defendant." And see id. at 15,938 (remarks of Senator Nelson); id. at 16,058 (remarks of Senator Clapp); id. at 15,825 (remarks of Senator Reed).

20. See sources cited note 19 supra.

21. The uncertainty of the effect of a guilty plea may be illustrated by the following colloquy on the Senate floor between Senator Walsh, a member of the conference committee that drafted the proviso, and Senator Reed:

Mr. Walsh. "That is what I wanted to inquire of the Senator [Reed]. He thinks the term 'consent judgment' would reach to a judgment entered on a plea of guilty?

Mr. Reed. "I think it would. . . . It is really a judgment by consent.

Mr. Walsh. "I would scarcely give that significance to that language.

Mr. Reed. "It is my opinion, from that language, that the deduction must be drawn that the exception applies to criminal as well as civil consents. The only way you can consent in a criminal case is by an absolute plea of guilty. . . .

Mr. Walsh. ". . . I scarcely think the Senator will care to say that judgments hereafter entered upon a plea of guilty would fall under the discrimination of consent judgments or decrees, because I take it that no criminal would even consent that a judgment be entered against him when he pleads guilty. The judgment goes as a matter of course against him.

“... I am not able to agree with the Senator that in the future the judgment entered upon a plea of guilty in a criminal action would not be available under the proposed statute."

Id. at 15,824-25. Recently several courts, although finding the history of Section 5 vague and "inconclusive," have resolved the uncertainty by holding that judgments rendered on guilty pleas are not exempt from the prima facie evidence provision of Section 5. See 
In addition, granting defendants an absolute right to plead nolo contendere contradicts the primary purpose of Section 5 . Section 5 and other provisions of the Clayton Act were responses to the recommendations of President Wilson, who had observed that it was "not fair that the private litigant should be obliged to set up and establish again the facts which the Government has proved"22 and had urged Congress to grant to parties injured by antitrust violations a "right to found their suits ... upon the facts and judgments proved and entered in suits by the Government." ${ }^{23}$ In the Clayton Act, Congress gave to private litigants not only the evidentiary benefit of Government judgments against the defendants but also several other aids designed to induce the plaintiffs to sue and to facilitate their action. Section 5 suspended the statute of limitations for instituting private actions during the pendency of Government proceedings. ${ }^{24}$ Section 12 extended venue against corporate defendants to any district in which they were found. ${ }^{25}$ Prior to 1914 a private litigant could sue a corporate defendant only in the district of which it was an inhabitant. ${ }^{26}$ Section 16 granted the private party the additional remedy of a suit for injunctive relief, which prior to 1914 was available only to the Government. ${ }^{27}$ The reach of the treble damage action was extended to the Wilson Tariff Act. ${ }^{28}$ And Section 4 granted to injured parties the right to sue

General Elec. Co. v. City of San Antonio, 334 F.2d 480 (5th Cir. 1964); City of Burbank v. General Elec. Co., 329 F.2d 825 (9th Cir. 1964); Commonwealth Edison Co. v. AllisChalmers Mfg. Co., 323 F.2d 412 (7th Cir. 1963), cert denied, 376 U.S. 939 (1964). Contra, Northwest Elec. Power Co-Op, Inc. v. General Elec. Co., 30 F.R.D. 557 (W.D. Mo. 1961) (ruling without discussion); Barnsdell Refining Corp. v. Birnamwood Oil Corp., $92 \mathrm{~F}$. Supp. 308 (E.D. Wis. 1940) (dictim); Twin Parts Oil Co. v. Pure Oil Co., 26 F. Supp. 360 (D. Minn. 1939) (dictum); Note, The Admissibility and Scope of Guilty Pleas in Antitrust Treble Damage Actions, 71 Yale L.J. 684, 688 (1962).

22. 51 CoNc. REc. 1964 (1914).

23. Ibid. Wilson also recommended that the statute of limitations on private actions be suspended during the pendency of a Government antitrust procecding. Ibid.

24. 38 Stat. 731 (1914), as amended 15 U.S.C. $₹ 16(\mathrm{~b})$ (1964). The effect of this provision and its substantial benefit to private suitors was dramatically illustrated by the litigation following United States v. Paramount Pictures, Inc., 334 U.S. 191 (1948). In that casc twelve years elapsed between the filing of the Government's action and the entry of final judgment, and it was held in subsequent cases that the statute of limitations for private actions was suspended throughout the period. See ATr'y Gen. Nat'L Comm. ANTImsust REP. 382-83, cases cited note 76 at 383 (1955).

25. 38 Stat. 731 (1914), 15 U.S.C. \& 22 (1964).

26. See H.R. REP. No. 627, 63d Cong., 2d Sess. 20 (1914).

27. See Paine Lumber Co. v. Neal, 244 U.S. 459 (1917).

28. $\$ \S 73-77$, ch. 349,28 Stat. 570 (1894) (amended by ch. 40, 37 Stat. 667 (1918), as amended, 15 U.S.C. $\$ \S 8-11$ (1964)). Section 73 of the Wilson Tariff Act declarcd illcgal agreements between persons engaged in importing goods into the United States if such agreements are intended to restrain trade or increase prices in the United States. 1 bid. 
for treble damages for violations of the "antitrust laws," a generic term which would allow private actions under subsequently enacted legislation aimed at restraints of trade. ${ }^{29}$ All of these aids to private litigants would be undercut by allowing the defendant to escape from private actions at his will.

Although the evidence and arguments against the "defendant's right" theory of Section 5 seem convincing and thus support the Government's change of policy in 1953, the evidence does not prove that the Government has a duty to oppose the acceptance of nolo pleas in every case. This other extreme position would require a reading of Section 5 which would be equivalent to giving private parties a right to a prima facie judgment in treble damage actions and to imposing upon the Government a duty to procure a judgment for the benefit of private suitors. This construction of the statute would subvert its policy by refusing to allow the Government to determine when it wishes to conserve prosecutorial resources.

Since Section 5 imposes neither of the extreme positions on the Government, it is free to exercise its discretion in determining when to oppose and when to acquiesce in a request for consent to plead nolo contendere. The discretion could be exercised either on an ad hoc basis or following principled guidelines. In practice the Government has not advanced any guidelines in individual cases but has assigned reasons for opposing nolo pleas which might serve as criteria for a consistent position. The following criteria have been considered important: (1) The seriousness of the violation. ${ }^{30}$ Per se offenses such as pricefixing, for example, have been considered serious enough by themselves to merit opposition to the plea. ${ }^{31}$ (2) The impact on the economy.32 This criterion has included the nature of the defendants-their prod-

29. In Nashville Milk Co. v. Carnation Co., 355 U.S. 373 (1958), however, the Supreme Court adopted a narrow reading of Sections 1 and 4 of the Clayton Act to exclude Scction 3 of the Robinson-Patman Act, 49 Stat. 1526 (1936), 15 U.S.C. $\S 13 \mathrm{a}$ (1964), as an antitrust law for violation of which a private treble damage action could be brought.

30. See, e.g., United States v. Standard Ultramarine \& Color Co., 137 F. Supp. 167 (S.D.N.Y. 1955); United States v. Westinghouse Elec. Corp., 1960 Trade Cas. 76,753 (E.D. Pa.); United States v. Burlington Industries, Inc, 1964 Trade Cas. 80,326 (S.D.N.Y.).

31. See, e.g., United States v. Toledo Milk Distribs. Ass'n, 1954 Trade Cas. 69,988 (N.D. Ohio); United States v. Burlington Industries, Inc, supra note 30. And sce, Address by Attorney General Robert F. Kennedy, American Society of Newspaper Editors, April 12. 1961:

Our general policy will be to oppose pleas of nolo contendere by defendants in pricefixing cases. . . Price-fixing is a serious matter.

32. See, e.g., United States v. Westinghouse Elec. Corp., supra note 30 (The Government estimated that over a billion dollars of sales to busineses, government agencies, and the general public were affected during the conspiracy). 
uct and volume of business-and the victims of the violations. (3) The flagrance of the violations. The practices engaged in, the manner of imposing restrictions, elements of wilfulness, fraud, or contempt for the antitrust laws have all been relevant. ${ }^{33}$ (4) The desire to secure the benefits of Section 5 for private litigants. ${ }^{34}(5)$ The desire to subject certain defendants to public censure. ${ }^{35}$

These criteria, however, have not been employed consistently. In other cases involving one or more of the considerations relied upon for opposition in earlier cases, the Government did not oppose the acceptance of the plea. In United States $v$. United States Steel Corp., ${ }^{\text {jo }}$ eight of the country's largest steel manufacturers were indicted for violation of the Sherman Act. The indictment charged the defendants with participation in a conspiracy consisting of a continuing agreement, during a period of at least six years, to eliminate price competition in the carbon steel sheet industry, ${ }^{37}$ which represented an estimated annual volume of business of $\$ 3.6$ billion. The investigation process lasted nearly two years and cost the Government hundreds of thousands of dollars. The case was considered among the most important of recent antitrust prosecutions; the Government was particularly interested in establishing price-fixing in order to discredit the theory that fluctuations in steel prices were the natural by-products of price

33. See, e.g., United States v. Safeway Stores Inc., 20 F.R.D. 451 (N.D. Tex. 1957) (Safeway had been convicted of antitrust violations on five prior occasions); United Statcs v. Cigarette Merchandisers Ass'n, 136 F. Supp. 212 (S.D.N.Y. 1055) (oppressive manner in which defendants imposed restrictions on victims); United States v. M. Klahr, Inc., 62 Cr. 347 (S.D.N.X. 1964), partially reported in 5 TRADE REG. REP. If 45,062, at 62,465 (charges in the indictment indicated moral turpitude-besides price-fixing and bid-rigging there were allegations of fraud, forging to create semblance of competitive bidding, and destroying records); United States v. H. P. Hood \& Sons, 63 Cr. 110.C (D. Mass. 1961) (Government charged the defendant's activities constituted calculated and deliberate contcmpt for the Sherman Act).

34. See, e.g., United States v. Cigarette Merchandisers Ass'n, supra note 83; United States v. Safeway Stores Inc., supra note 33.

35. See, e.g., United States v. American Oil Co., supra note 10; United States v. Union Plate \& Wire Co., 56 Cr. 83 F (D. Mass. 1957) (Defendant issued press release stating that the filing of charges by the Antitrust Division was unwarranted and without legal justification. The Government considered this as inconsistent with a desire to plead nolo).

36. 64 Cr. 344 (S.D.N.Y. 1965); partially reported in 5 TRADE REG. REP. If 45,064, at 52,556. See also, United States v. Bethlehem Steel Co., 62 Cr. 393 (S.D.N.X. 1965) 5 TradE REG. REP. I 45,062, at 52,469; United States v. United States Steel Corp., 63 Cr. 312 (S.D. N.Y. 1965) 5 TRADE REg. ReP. 45,063 , at 52,520 .

37. Carbon steel sheet is used in the manufacture of automobile bodics, washing ma. chines, refrigerators, kitchen cabinets, office furniture and other products. It accounts for approximately one-third of the total shipments of finished steel mill products in the United States. Indictment, I Antitrust Pleading File, United States v. United States Stcel Corp., 64 Cr. 344 (S.D.N.Y. 1965). 
leadership unaffected by agreements among the members of the industry. And, according to a Government attorney, the activities of the defendants had "one of the greatest impacts [on the economy] in recent antitrust history." 38

Nevertheless, the Government quite unexpectedly acquiesced in the defendants' tender of nolo contendere pleas, which were promptly accepted by the court. According to the Government, the case presented the following "special circumstances" which justified its failure to protest: (1) acknowledgments by the defendants that they had engaged in some of the activities enumerated in the indictment, (2) the defendants' discontinuation of the violations prior to the commencement of the grand jury investigation, and (3) the defendants' representations that subsequent treble damage actions were unlikely. ${ }^{39}$

In view of the importance of the case and the magnitude of the violations it is not easy to accept these reasons as "special circumstances." The relevance or value of the defendants' qualified acknowledgment ${ }^{40}$ of participation in some of the activities charged in the indictment is questionable. When any defendant pleads nolo contendere, by the very nature of the plea, he admits the facts charged in the indictment for the purposes of the case and is punished on the basis of that admission. If the Government's reasoning in Steel were followed, defendants could create the "special circumstances" necessary to have a nolo plea accepted simply by pleading nolo. The second reason assigned-the defendants' allegation that the illegal practices charged had been discontinued prior to the grand jury investigation-is no more convincing. There is nothing unique in discontinuation; it is probably true of most prosecutions. The seriousness of the violations is in no way mitigated by the Government's belated investigation. And the third consideration is equally unconvincing. It is quite curious that the Government's decision rested upon the defendants' representations about the unlikelihood of "many" treble damage actions. It seems inconceivable that after two years of investigation the Government would

38. Stenographer's Minutes, Hearing before Judge Weinfeld, July 23, 1965, United States v. United States Steel, 64 Cr. 344 (S.D.N.Y. 1965).

39. Ibid.

40. The defendant's acknowledgment read as follows:

While the defendants acknowledge they participated in some of the activities referred to in the indictment, whether or not these activities constitule a violation of law would be for the jury ultimately to decide. Such reference to the character of the meetings is ... made . . because a charge of price-fixing may be levied against many kinds and gradations of conduct. [Emphasis added.]

Memorandum in Support of Defendants' Applications for Leave to Plead Nolo Contendere 3, III Antitrust Pleading File, United States v. United States Steel Corp., supra note 37. 
need to be informed by the defendants that private actions were unlikely. Acceptance of the defendants' forecast of treble damage liability was proven unrealistic during the sentencing proceedings in the case. At that time, the Government requested the maximum fine and brought forth evidence which showed the far reaching impact of the violations. ${ }^{41}$ The evidence, briefly put, seemed to contradict the defen. dants' forecast. This third reason for acquiescing again raises the question of the propriety of allowing the defendant to create his own special circumstances. Quite aside from accepting defendant's claims about the likelihood of treble damage action, in other cases the Government has considered the necessity for a clear public record of the defendant's activities as overriding and has opposed the plea even though treble damage actions were unlikely. ${ }^{42}$

In other similarly important prosecutions the Government has unexpectedly reversed its earlier opposition to the nolo plea, advancing in support of its reversal criteria which on other occasions it has dismissed as improper grounds for accepting the plea. In United States $v$. Anaconda American Brass Co., ${ }^{43}$ although the Government's attorney thought the activities of the defendants to constitute "as flagrant a price fixing conspiracy as I would like to come across,"44 the Government changed its original position and did not object to the acceptance of the plea from thirteen out of eighteen defendants. The same attorney explained to the court that "our reason for assenting to the nolo pleas is because it disposes [of the case] as well as a conviction in a trial could do." 45 That statement questions the entire basis of the Government's practice of opposing nolo pleas. And in United States v. Bethlehem Steel Co.46 the Government reversed its position on the defendants' third request for leave to plead nolo. The Government attorney explained his new position by stating that acceptance of the plea would save time and clear the court's calendar. ${ }^{47}$ Of course these two reasons were just as applicable to the defendants' two prior attempts, as they are applicable to every case. What is more important is that on other occasions, when the case had some special significance, the Govern-

41. Stenographer's Minutes, Hearing before Judge Weinfeld, supra note 38 .

42. See, e.g., United States v. American Oil Co., supra note 10.

43. Cr. No. 10,725 (D. Conn. 1963).

44. Transcript of Proceeding before Judge Blumenfeld, February 11, 1963, United

States v. Anaconda American Brass Co., supra note 43.

45. Ibid.

46. Note 36 supra.

47. N.Y. Times, July 27,1965 , p. 1, col. 2. 
ment has declared that saving time is an improper consideration in determining whether the plea should be accepted..$^{4}$

These recent cases illustrate what seems to be an inconsistent application of reasons usually given for opposing nolo contendere pleas and a lack of any established standards used by the Government in its administration of the plea. It is quite possible that the Government has other reasons which would explain the cases. ${ }^{20}$ As long as the reasons remain undisclosed, though, it will be impossible to know whether the Government is still attempting to implement the policy announced by the Attorney General in 1953. The acquiescence of the Government in these cases at least invites inquiry. Less visible, yet equally subject to inquiry, is the position of the Government in the cases in which it neither opposes nor acquiesces. Unless silence is to be read as acquiescence, the Government's position in these cases is impossible to analyze. It would be preferable for the Government to state its position in each case so that critics could determine whether or not it is applying its criteria consistently, and also to give the courts that rely on the Government rational guidelines to follow.

\section{The Attrtudes of the Courts}

At least in theory the Government's position does not determine whether or not the nolo plea will be accepted. Rule II of the Federal Rule of Criminal Procedure gives the courts, not the Government, discretion to accept the plea. But the courts have differed on the scope of this discretion. Three possible views seem to emerge from the cases. First, Rule 11 may be read as an extremely generous grant of discretion to accept or reject the plea regardless of the Government's position. ${ }^{50}$ Second, Rule 11 may be disregarded by allowing the Govern-

48. See, e.g., United States v. B. F. Goodrich Co., 1957 Trade Cas. 72,871, 72,872 (D.C.).

49. The Government's mysterious conduct in this and companion cases gave rise to speculation whether they represented an official reversal of the Government's policy with regard to nolo pleas. In a statement shortly after the disposition of the steel cases on nolo pleas, the Assistant Attorney General in charge of the Antitrust Division. Donald F. Turner, declared:

We are in the process of trying to reconsider policy as to when a nolo plea vill be accepted and when it won't.

N.Y. Times, July 28, 1965, p. 1, col. 3. However, Mrr. Turner indicated in a letter of November 5, 1965, to the Yale Law Journal that the Government's position in the sted cases did not represent any revised policy. It may be significant to note, however, that the cases came up for disposition during the labor contract negotiations between the steel industry and workers, that the strike deadline was nearing, and that the President $\infty$ pressed interest in averting a shutdown.

50. This view appears to be accepted by the many courts which have established in- 
ment complete freedom to decide the issue. ${ }^{51}$ Finally, a court may take an intermediate position by allowing the Government freedom, but using Rule 11's discretion to ensure that the Government is consistent and fair.

dependent criteria to override the opposition of the Government in the majority of cases in which the Government has lodged a protest to nolo pleas. These courts have rested their decisions principally on their discretion under Rule 11 without adequatc examina tion of the demands of Section 5 of the Clayton Act. An argument could be made that Section 5 does not sanction the practice of a court overriding the Government's desire for full prosecution and that the existence of independent court discretion to accept a nolo plea under Rule 11 in antitrust cases is inconsistent with the purposes of Section 5, a consideration probably overlooked by the draftsmen of the Rule. When the Government opposes a nolo plea it in effect indicates an interest in promoting the policy of the body of Section 5 by securing a judgment to assist private suitors. It also indicates a choice not to spare its resources in the particular case. The reading of the proviso as a tool for the Government to minimize its antitrust litigation burden would require the Govern. ment to exercise full control over application of the proviso. Hence it could not be up to the defendants nor up to the courts to decide unilaterally when the Government should be relieved of a prosecution, especially one that it wishes to litigate fully. And the impracticality of allowing independent court discretion over the application of the proviso is illustrated by the inevitable one-sidedness of that discretion. Full discrction would entail power to override the Government even when it does not want to prosecute fully, i.e., when it acquiesces in the offer of a nolo plea or when it actually suggests to the court that the plea be accepted. In practice that does not occur; the courts have acted independently only to override an objection. Overriding a suggestion for acceptance would be extraordinary. When the Government registers no opposition, there is little that the courts can do to override that discretion, especially in view of the fact that the decision is departmental rather than that of a single prosecutor. The courts could not compel the Government to prosecute fully; if they reject the Government's suggestion to accept a nolo plea, the Government can drop the prosecution if it wishes not to procced. Moreover, the Government's decision not to proceed fully may be based upon national policy considerations that a court may not be aware of unless it compels their disclosure. This the courts would be reluctant to do, just as the Government may occasionally prefer not to reveal the real reasons underlying its decision.

51. Some courts have recognized their limitations in this area, and have deferred to the Government's determination in spite of their own inclinations to the contrary. Sce, e.g., United States v. Minnesota Mining and Mfg. Co., 5 Trade REg. REp. (1966 Trade Cas.) I 71,649 (E.D. Ill.). A few courts have endeavored to establish independent standards to reject nolo contendere pleas. These courts sometimes express hostility towards nolo contendere pleas. See, e.g., United States v. Pittsburgh Plate Glass Co., 1957 Trade Cas. 73,327, at 73,328 (W.D. Va.) (The court expressed a "general disinclination to accept pleas of nolo contendere for the reasons that it thought they were in the nature of 'ficcsaving' pleas and were tendered because the defendants did not wish to bear the supposed odium of pleading guilty, although they might in fact be guilty of the offense charged and know that they were guilty.") They also generally assert that they require a positive showing by the defendants of circumstances entitling them to the benefits of the nolo plea. See, e.g., United States v. Pittsburgh Plate Glass Co., supra, at 73,328; United States v. Standard Ultramarine \& Color Co., 137 F. Supp. 167 (S.D.N.Y. 1955). The most essential factor considered by these courts is whether the public interest will be better served by acceptance or rejection of the plea. See, e.g., United States v. Standard Ultramarine \& Color Co., supra; United States v. McDonough Co., 1960 Trade Cas. 76,787 (S.D. Ohlo). 
Regardless of which position the courts have, in fact, adopted there seems to be striking uniformity in outcome. Statistics indicate that the courts have been overwhelmingly sympathetic to nolo contendere pleas. Between 1935 and 1950 nolo pleas were allowed in 181 antitrust prosecutions and rejected in none. ${ }^{62}$ Between 1954 and 1964 the plea was accepted from some or all defendants in 167 cases $^{53}$ and refused in

One court cited the following criteria as important in this determination: (1) the nature of the violation-how serious, the length of time engaged in, the practices involved, and the extent of the defendant's participation; (2) the nature of the defendant-its size and power in the industry, the importance of the product, and the record of prior violations; (3) the impact of the violations on the economy; (4) the deterrent effect resulting from acceptance or rejection; and (5) the position of the Government. United States v. Stan. dard Ultramarine \& Color Co., supra at 172. Other courts have assigned one or more of these reasons in rejecting nolo pleas. See, e.g., United States v. Toledo Milk Distribs. Ass n, 1954 Trade Cas. 69,988 (N.D. Ohio) (price-fixing in vital industry); United States v. Westinghouse Elec. Corp., 1960 Trade Cas. 76,753 (E.D. Pa.) (court influenced grealy by the position of the Government).

Close observation reveals, however, that in the cases in which the plea has been rejected the Government's protest has been the decisive factor and that the arguments countenanced by the courts in denying the plea have in fact been those advanced by the Government. No case is known in which a nolo plea has been refused in the absence of Government pratest or against the Government's suggestion that it be accepted. That result is not surprising. The determination of whether the public would be better served by a rejection of a nolo plea is a policy decision which the Government is more competent to make. It has the pertinent data concerning the offense and the offenders from which it can assess the impact of full prosecution from a national perspective. Since the Government's decision to contest a nolo plea theoretically is based on the same public interest consideration, the court would merely echo the Government's determination if it rejects a plea which the Government has opposed. If, on the other hand, the Government indicates that the case should be disposed of by a nolo plea, the courts' "independent" standards are undercut. If the court disagrees, it would have to make a contrary policy determination. The court would also have to make the unusual decision to tell the Government to proceed with a case that the Government may prefer not to prosecute fully. This the courts have felt constrained to do. Instead, some courts bave taken the absence of Government remonstrance to a nolo plea as itself indieating that the public interest will be sufficiently vindicated if the plea is accepted. Sec, e.g., United States v. Minnesota Mining and Mfg. Co., supra at 81,904, where the court declared:

In view of the statements of counsel for the government made both orally and in written briefs and in view of the interpretation that the Court places on the government's position in not opposing such a plea that no public harm would ensue in accepting the nolo contendere plea and in spite of this Court's disfavor of such a plea. I did accept the plea of nolo contendere of this defendant.

Thus these courts in effect acknowledge that their discretion to accept nolo contendere pleas in antitrust cases is circumseribed by the position taken by the Government.

52. See Yankwich, Observations on Anti-Trust Procedures, 10 F.R.D. 165, 166 (1951), and United States v. Westinghouse Corp., 1960 Trade Cas., supra note 51, at 76,756 (angument of defense counsel).

53. Brief in Support of Defendants' Entry of Nolo Contendere Pleas, I Antitrust Pleading File, United States v. American Oil Co., 65 Cr. 150(3) (E.D. Mo. 1965). The criminal cases disposed of between July, 1955 and 1962 break down as follows: 
only $25 .{ }^{54}$ The figures are more impressive if put in terms of the number of defendants allowed to enter nolo pleas. During the period 1956 to 1964 nolo pleas were accepted from 916 out of the 1130 (81\%) defendants convicted and sentenced in connection with federal antitrust violations. ${ }^{55}$ Even Government opposition to the plea has not significantly deterred court acceptance. Between 1954 and 1964 the courts allowed nolo pleas over the objection of the Government in 99 of the 124 contested motions. ${ }^{50}$

A study of the latter group of cases might indicate why the courts

Nolo Contendere as to all defendants

Nolo Contendere as to some defendants

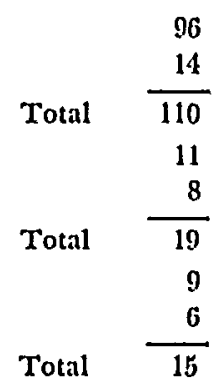

Guilty pleas as to all defendants

Guilty pleas as to some defendants

Criminal cases actually tried as to all defendants

Criminal cases actually tried as to some defendants

96

$\frac{1}{10}$

19

54. Disposition of Antitrust Cases Where the Government Opposed Entry of Nolo Contendere Pleas, 1954 to August 1964, I Antitrust Pleading File, United States v. H. I. Hood \& Sons, Inc., 63 Cr. 110-c (D. Mass. 1964).

55. The breakdown was as follows:

Defendants Convicted and SENTENCEd

\begin{tabular}{|c|c|c|c|c|c|c|c|}
\hline \multirow{2}{*}{$\begin{array}{l}\text { Fiscal } \\
\text { Year }\end{array}$} & \multirow[b]{2}{*}{ Total } & \multirow{2}{*}{$\begin{array}{l}\text { Plea } \\
\text { Guilty }\end{array}$} & \multirow{2}{*}{$\begin{array}{c}\text { Plea } \\
\text { Guilty, } \\
\text { Initial } \\
\text { Plea Not } \\
\text { Guilty }\end{array}$} & \multirow{2}{*}{$\begin{array}{c}\text { Plea } \\
\text { Nolo } \\
\text { Conten- } \\
\text { dere }\end{array}$} & \multirow{2}{*}{$\begin{array}{c}\text { Plea } \\
\text { Nolo, } \\
\text { Initial } \\
\text { Plea Not } \\
\text { Guilty }\end{array}$} & \multicolumn{2}{|c|}{$\begin{array}{l}\text { Convicted } \\
\text { by }\end{array}$} \\
\hline & & & & & & Court & Jury \\
\hline 1964 & 143 & 2 & 6 & 51 & 78 & 3 & 3 \\
\hline 1963 & 118 & 1 & 5 & 42 & 70 & - & - \\
\hline 1962 & 69 & 2 & - & 22 & 31 & 18 & 1 \\
\hline 1961 & 153 & 9 & 48 & 25 & 58 & - & 18 \\
\hline 1960 & 106 & - & - & 12 & 91 & 3 & - \\
\hline 1959 & 133 & 1 & 10 & 31 & 81 & 6 & 4 \\
\hline 1958 & 144 & - & 1 & 13 & 100 & 10 & 20 \\
\hline 1957 & 100 & 9 & 15 & 41 & 28 & 1 & 6 \\
\hline 1956 & 164 & 5 & 11 & 33 & 109 & 4 & 2 \\
\hline Total & 1130 & 29 & 96 & 270 & 646 & 40 & 49 \\
\hline
\end{tabular}

This table was obtained from the Division of Procedural Studies and Statistics, Adminis trative Office of United States Courts.

56. Disposition of Antitrust Cases Where the Government Opposed Entry of Nolo Contendere Pleas, note 54 supra. 
have seemed so receptive to nolo pleas. In accepting the plea over protest by the Government the courts usually rest their decisions on (1) the policy of the proviso to Section $5,(2)$ reasons of judicial administration, and (3) special circumstances present in the individual case.

Section 5 Arguments. Many courts purport to find the endorsement of congressional policy to support their decision to allow nolo contendere pleas. They stress that in the proviso to Section 5 Congress intended to favor defendants who accept the invitation to capitulate without trial, and that disposal of cases by nolo pleas is consonant with that declared position. ${ }^{57}$ As a corollary to this argument, some courts maintain that the responsibility of the government to vindicate the public interest does not extend to securing judgments that could be utilized by private litigants. According to one court, for example, Congress did not intend that "pleas of nolo contendere be refused in criminal antitrust cases for the purpose of aiding private litigants under Section 5 of the Clayton Act." 58

In essence, and occasionally in fact, these courts have construed the proviso as conferring upon the antitrust defendant an "unqualified right to capitulate," 59 or as containing implicitly a congressional command to favor those defendants who surrender. As shown earlier, ${ }^{\text {co }}$ this reading is not reasonable, especially when the Government, by opposing the plea, expresses its readiness to go to trial and to use its prosecutorial resources. The corollary argument against the Government's attempt to procure a prima facie judgment for private suitors is equally unsatisfactory, and like the core argument reads the proviso

57. Although the courts generally recognize that private treble damage suits by those who have been injured by antitrust violations have the effect of making the antitrust laws more effective, there is to be found in the section quoted an unmistakable intent on the part of Congress to say to the law violators that, if they will capitulate by a consent decree before any testimony has been taken, then the provision as to the judgment in favor of the Government being prime facie evidence in private litigation will not apply.

Inited States v. Minneapolis-Honeywell Regulator Co., 1963 Trade Cas. 78,494, at 78,495 ). Minn.). See United States v. B. F. Goodrich Co., 1957 Trade Cas. 72,871 (D. Colo.). 58. United States v. Safeway Stores, Inc, 20 F.R.D. 451, 457 (N.D. Tex. 1957). But see zited States v. Standard Ultramarine \& Color Co., 137 F. Supp. 167, 172 (S.D.N.Y. 1955). 59. See, e.g., United States v. Brunswick-Balke-Collender Co., 203 F. Supp. 657, 662 D. Wis. 1962) ("The right given to antitrust defendants by the proviso of $\$ 5$ to avoid 'prima facie evidence' sanction by capitulation is an unqualified right.' ); United States Vard Baking Co., 1963 Trade Cas. 77,499 (M.D. Fla.), vacated and remanded, 376 U.S. (196t). But see Dabney, Consent Decrees Without Consent, 63 Corus. L. REv. 1053, -69 (1963).

- See text accompanying notes $16-30$ supra. 
in a vacuum. It is not true that Section 5 prevents the Government from seeking to ease the burden of potential treble damage plaintiffs. Congressional efforts to facilitate private antitrust actions by making Government judgments available to private suitors would be undercut if the Government did not exert itself to secure the judgments upon which the success of the private enforcement scheme rests. The courts which have correctly thought it necessary to justify the exercise of their discretion under Rule 11 in terms of Section 5 have incorrectly focused their attention on the proviso alone. To discount the Government's efforts on behalf of a private plaintiff is as unsatisfactory as to overlook Section 5 altogether.

Judicial Administration. The courts which have relied upon arguments concerning judicial administration to override Government opposition to nolo pleas seem, in fact, to have ignored Section 5 . These arguments have usually been based upon a desire to expedite litigation, presumably because the public interest so compels. Although the courts consistently claim that the condition of the dockets and saving time can never justify accepting the plea, in numerous cases they have left no doubt that judicial economy has been a decisive factor in the acceptance of nolo pleas. ${ }^{6 x}$ Thus, in United States $v . B . F$. Goodrich $C o .{ }^{82}$ the court noted that it would allow nolo pleas only upon a show. ing by the defendants of "exceptional circumstances." The only exceptional circumstance alleged by the defendants was the possibility of exposure to greater treble damage liability. The court met this surprisingly candid admission with the argument that if the desire to be shielded from potential treble damage liability constituted an "excep. tional circumstance" it would exist in almost every Sherman Act prosecution. Nonetheless, the court granted the defendants' motion

61. See, e.g., United States v. Burlington Indus., 1965 Tradc Cas. 80,619 (S.D.N.Y); United States v. Milk Distribs. Ass'n, Inc., Crim. No. 25658 (W.D. Md. 1962); United States v. B. F. Goodrich Co., 1957 Trade Cas. 72,871 (D. Colo.); United States v. Safeway Stores, 20 F.R.D. 451 (N.D. Tex. 1957). In the latter case, the court expressed this view as follows:

While the condition of the Court's docket would not be teason for the acceptance of the pleas of nolo contendere, the fact is that all other litigation in the Fort Worth, Abilene and San Angelo Divisions of the Northern District of Texas would necessitlly be delayed and all other litigants would be denied the right to speedy trial durlng the trial of this case, estimated at a minimum of three months, if such pleas be not accepted. The benefits to be derived from a long, expensive trial are not sufficient in the instant case to justify the rejection of the defendants' offered pleas of nolo con tendere. The saving of time and expense has been recognized as a factor in the ac ceptance of pleas of nolo contendere.

Id. at 458 .

62. 1957 Trade Cas. 72,871 (D. Colo.). 
because

the public interest requires that everything be done which can properly be done to expedite the trial and disposition of lawsuits. In this case a lengthy trial is prophesied. The elimination of such a trial will make available court time for the handling of other litigation which has been long delayed. ${ }^{03}$

The court added that although congestion of the court's calendar is not a controlling reason for granting consent to a nolo plea, "it is a factor which a trial judge may not blithely ignore." 04 Thus, the court created its own "exceptional circumstance," which was no more satisfactory than the one offered by the defendants.

It is understandable for the courts in exercising their discretion to concern themselves with the drain on their time and energy and with access to the courts by other litigants. But there is little justification for sacrificing one class of plaintiffs. Why should the court choose between antitrust plaintiffs and plaintiffs in tort, contract, or divorce actions? In addition, the reason assigned by the courts for their position-the public interest in uncluttered dockets-is hardly sufficient. Freeing the docket can benefit only the defendants in the particular antitrust case and the small segment of the public which may then be engaged in litigation. The larger public interest in effective administration of the antitrust laws certainly deserves greater consideration.

In some cases a decisive factor relied upon by the courts has been the pendency of a companion Government civil action based on the same facts as the criminal proceeding. ${ }^{\text {os }}$ Courts facing this situation have said that "[I]t would be an unconscionable waste of the manpower of this court and of the litigants to have two protracted trials involving substantially the same proof." 60 Some courts add the observation that the judgment rendered in the civil action will be available to private litigants as prima facie evidence, thus replacing the benefit

63. Id. at 72,878. The court had requested that the matter of the congestion of the court's docket be brought to the attention of the Attorney General, who later conveyed "a very sympathetic concern" for the congestion of the calendar but felt that this was not a factor to be considered in the decision on a nolo plea. Id. at 72,872. The defense counsel then quite shrewdly reminded the court that ". . . the discretion is not Mrr. Brownell's [Attorney General] or Mr. Hansen's [Assistant Attorncy General, Antitrust Division] who sit in air-conditioned offices in Washington but it is yours who sits [sic] behind the bench in an un-air-conditioned courtroom here." Id. at 72,873 .

64. Id. at 72,876 .

65. See, e.g., United States v. Burlington Indus., 1965 Trade Cas. 80,013 (S.D.N.Y.); United States v. Burlington Indus., 1964 Trade Cas. 80,326 (S.D.N.Y.); United States v. Cigarette Merchandisers Ass'n, 136 F. Supp. 212 (S.D.N.Y. 1955).

66. United States v. Cigarette Merchandisers Ass'n, supra note 65, at 213. 
lost when the defendant pleads nolo in the criminal case. ${ }^{07}$ The shorthand version, in the words of one court, is: ". . . [A] judgment in one action would thus accomplish the same result as a judgment in two." 08 Unfortunately, the courts and private litigants cannot be accommodated so easily.

The argument does not take into account that in practice Government civil antitrust actions are usually settled out of court by consent decrees, ${ }^{69}$ which are immune from the effects of Section 5. By accepting the nolo plea of a defendant confronted with simultaneous Government civil and criminal actions the court affords that defendant a great tactical advantage. If the nolo plea is accepted before the disposition of the civil action, defendant can come to terms on a consent decree in the civil suit, thereby avoiding the effects of Section 5 in both proceedings. It may be argued that the Government can always refuse to consent to the civil decree and insist upon a trial for the purpose of securing a judgment for the benefit of private parties. But there are indications that the courts will not view this strategy favorably. ${ }^{70}$ In

67. See, e.g., United States v. Burlington Indus., 1965 Trade Cas. 80,618 (S.D.N.Y.); United States v. Burlington Indus., 1964 Trade Cas. 80,326 (S.D.N.Y.). In the former case the court declared: "I do not believe it is in the public interest to burden the criminal calendar of this court for the benefit of private litigants who will receive all the benefits which the law may have intended to grant them. . . " 1965 Trade Cas. at 80,615 .

68. United States v. Burlington Indus., 1964 Trade Cas. 80,326, at 80,327 (S.D.N.Y.). The courts cannot make these sweeping statements about the effect of the judgment in the Government's civil action without first examining the nature of that civil action. If the Government's civil proceeding is one for damages alone under $\S 4 \mathrm{~A}$ of the Clayton Act, the courts would be totally wrong in asserting that the benefits of a prima facie judgment would be preserved. Under the proviso as amended by the Act of July 7, 1955. 69 Stat. 282, 15 U.S.C. $\$ 16$ (1964), judgments entered in procecdings brought by the Government under $\S 4 \mathrm{~A}$ are exempt from the prima facie evidence effect of the body of § 5. If the Government's civil action is for injunctive relicf alone, a judgment entered after trial would be available to private litigants as prima facie cvidence. If the Government action is simultaneously for damages and injunctive relief, however, the statutc is silent.

69. In the three year period 1962-1964, for example, the Government terminated 117 civil cases. Of these, 92 , or $79 \%$ of the total, were concluded by consent decrecs. Letter to the Yale Law Journal from the Administrative Office of United States Courts, October 14, 1965, on file in the Yale Law Library. The breakdown is as follows:

$1962 \quad 1963 \quad 1964$

Civil Cases Terminated

$\begin{array}{lll}14 & 65 & 88 \\ 11 & 51 & 30\end{array}$

Civil Cases Terminated by Consent

70. See, e.g., United States v. Brunswick-Balke-Collender Co., 203 F. Supp. 657, 661 (E.D. Wis. 1962): "We do not believe that anything in $\S 5 \ldots$ requires or authorizes the Government to continue to prosecute litigation where the only remaining purposc of the continued prosecution is the establishment of certain benefits for treble damage claimants." 
United States v. Brunswick-Balke-Collender Co.i1 a nolo plea was accepted in the parallel criminal action, a consent decree had been negotiated in the civil case, and the defendant had acceded to its terms. The Government, however, had not formally given consent. While the litigation was pending the Government instituted a policy which required, as a condition to its grant of consent to a decree, that the defendant agree to concede guilt in treble damage actions by certain claimants. ${ }^{72}$ The Government thus sought to overcome the operation of the proviso to Section 5. But the defendant moved for a judgment without the condition demanded. The Government argued that it had a right to refuse consent and insist upon a trial even though the defendant had agreed to all the relief which the Government could obtain at trial. The court rejected this argument and entered a consent decree without the Government's consent. ${ }^{73}$

Courts that rely on parallel civil actions when accepting nolo pleas also gloss over the essential differences between the two methods of redressing injuries and ignore the objectives that prompt the Government to initiate two proceedings. The civil action is brought to secure an order enjoining the defendant from further participation in the proscribed conduct and also to obtain past damages for any injury suffered by the Government as a consumer. But when the Government initiates a criminal proceeding, it seeks more than prohibitory and compensatory remedies; it seeks the additional sanctions of fines, possible jail sentences and social stigma, none of which is provided by the civil action.

\footnotetext{
71. 203 F. Supp. 657 (E.D. Wis. 1962).

72. The Government attempted to preserve the benefits of $\S 5$ in any suit brought against the defendants by a state or political subdivision. Ibid.

73. The same strategy was involved in United States v. Lake Asphalt \& Petroleum Co., 1960 Trade Cas. 77,271 (D. Mass.), discussed in Dabney, Consent Decrees Without Consent, 63 CoLum. L. REv. 1053, 1058 (1963). Some of the defendants refused to accede to the waiver provision demanded by the Government and requested a judgment without it. The court denied the motion for judgment and ordered the case for trial. However. the judge declared that although he was "willing to believe that the court had power" to grant the motion, he declined to exercise it as a matter of discretion. Dabncy, supra at 1058.

In United States v. Ward Baking Co., 376 U.S. 327 (1964), the Supreme Court declined to rule on the question whether the Government may properly refuse consent to a decree and insist upon a trial in cases where there is complete agreement on every substantive item of relief. The Court held that a consent judgment could not be rendered without the Government's consent if there existed a genuine controversy about an item of relief to which the Government may show at trial that it is entitled. In this case the Government's refusal to consent was based not on an attempt to by-pass the proviso to $\S 5$ for the benefit of private litigants but on a desire to obtain brosder injunctive relicf than the defendants were willing to accept.
} 
If the nolo plea is rejected, and it becomes necessary to adjuclicate both the civil and the criminal actions, the courts' fear of extensive relitigation of the same issues is overstated. By application of the principles of collateral estoppel the issues actually raised and determined in a prior action are established conclusively between the same parties and cannot be relitigated subsequently. ${ }^{74}$ Under the Supreme Court's ruling in Emich Motors Corp. v. General Motors Corp., ${ }^{75}$ these principles of estoppel have been found in Section 5, which permits the Government, in its civil action, to introduce as prima facie evidence of violation the judgment entered in the companion criminal proceeding. The estoppel, as defined by the Court, extends to "all matters of fact and law necessarily decided by the conviction and the verdict on which it was based."76 Moreover, the disposition of the second case may be expedited in some instances by the rules of evidence, particularly those relating to admissions. ${ }^{77}$

Finally, acceptance of a nolo plea simply to avoid the duplication of a criminal trial and a civil trial presupposes that the defendant who cannot plead nolo will invariably plead not guilty and force the Government to trial. But the defendant may himself wish to avert a trial. Of the 25 cases recorded between 1954 and 1964 in which the courts refused nolo pleas, the defendants subsequently pleaded guilty in at least $15 .^{78}$

Special Circumstances. In numerous cases the presence of special circumstances peculiar to the particular case has been relied upon by the courts in accepting the nolo plea over the Government's protest. Circumstances such as the alleged good faith of the defendant, his willingness to submit to and cooperate with the Government, ${ }^{70}$ his

74. See Local 167, Int'l Bhd. of Teamsters v. United States, 291 U.S. 293, 298 (1984); United States v. Greater New York Live Poultry Chamber of Commerce, 53 F.2d 518 (S.D.N.Y. 1931). And see generally Scott, Collateral Estoppel by Judgment, 56 HARv. L.

REv. 1 (1942).

75. 340 U.S. 558 (1951).

76. Id. at 569 .

77. The making of judicial admissions by defense counsel in Government antitrust proceedings has been cited as one of the chief "pitfalls" for a defendant who may subscquently have to defend private actions. Seeley, The Pitfalls Which Lurk in Government Litigation for Defendants Who May Be Subjected to Treble Damage Actions, 4 ANtrraust Bull. 17 (1959).

78. This figure was obtained by scanning the Antitrust Pleading File of cach of the 25 cases in which the nolo contendere plea was rejected.

Of course, guilty pleas will encourage rather than discourage private actions. So it would be of no comfort to a court to reject a nolo plea and invite a guilty plea along with an increased amount of private litigation.

79. See, e.g., United States v. Minneapolis-Honeywell Regulator Co., 1963 Tradc Cas. 
inadvertence or lack of intention in committing the offense, ${ }^{80}$ his relatively minor role in the violation, ${ }^{81}$ the absence of a previous record of convictions or violations, ${ }^{82}$ and the prior grant of consent to plead nolo to other defendants in the same case ${ }^{83}$ have been cited and held to constitute special circumstances.

The existence of special circumstances may in proper cases be justified as a consideration to be weighed in a ruling on a nolo plea. However, the courts have at times overemphasized the importance of mitigating circumstances and, by relying on them to accept nolo pleas, have overlooked the demands of Section 5.84 In cases of serious violations

78,494 (D. Minn.). The defendants alleged that they had shown good faith by terminating the unlawful practices prior to the commencement of any Government investigation and offered to submit to a consent decree in the Government's civil case.

80. See, e.g., United States v. Pittsburgh Plate Glass Co., 1957 Trade Cas. 73,327 (W.D. Va.). The court did not accept the plea because the defendants did not make out an adequate showing that the case was a proper one for disposal by nolo contendere. But it permitted the defendants to renew the motions, noting that the plea would be accepted where the facts showed an inadvertent violation or one not accompanied by wrongful intent.

81. See, e.g., United States v. Engelhard-Hanovia, Inc., 1964 Trade Cas. 79,161 (S.D. N.Y.). Defendant's participation in the violation was of a shorter duration and of a lesser degree than that of the other defendants. And defendant's share of the industry's gross sales amounted to approximately $3 \%$, as opposed to $48 \%, 21 \%$ and $20 \%$ for other defendants.

82. See, e.g., United States v. Burlington Indus., 1964 Trade Cas. 80,326 (S.D.N.Y.) (Defendant, in business for over sixty years, had never before been changed with a violation of the antitrust laws.); United States v. Minneapolis-Honeywell Regulator Co., 1963 Trade Cas. 78,494 (D. Minn.).

83. In United States v. Blaw-Knox Corp., 63 Cr. 602 (S.D.N.Y. 1965), one defendant was permitted to enter a nolo plea which the Government did not oppose. Subsequently a second defendant requested leave to plead nolo contendere. The Government objected. but the plea was allowed when no sufficient showing was made for the difference in treatment of the defendants. Nolo pleas were thereafter accepted from the remaining defendants for the same reason. In United States v. Burlington Indus., 1965 Trade Cas. 80,613 (S.D.N.Y.), this practice was carried one step further. One defendant had been allowed to plead nolo but, unlike the Blaw-Knox case, over the vigorous protest of the Government. Later five other defendants applied to a different judge for consent to enter nolo contendere pleas. Among other things, the court declared that it was in agreement with the result in Blaw-Knox in accepting the plea on the ground that another defendant in the same case had previously been allowed to enter a nolo plea.

84. In United States v. Burlington Indus., supra note 83, the defendants were charged with a serious price-fixing conspiracy in glass fiber industrial fabrics, a product which the Government alleged was essential to the national defense. As a result of the conspiracy. the Government also alleged, defense costs were increased and substantial private injury was caused. To the Government's charges regarding the seriousness of the violation, the court answered: "Recognizing the gravity of the offense, is this sufficient grounds, in itself, to warrant denial of the plea? I think not." Id. at 80,615. The court accopted the plea relying heavily on the special circumstance of a government civil action against the defendants for the same offense. 
where substantial private injury has resulted, the policy of Section 5 should override any special considerations that would deny the evidentiary aid to injured parties and permit defendants to avoid private liability. The court may always rely on the special circumstances to mitigate the punishment it may impose upon conviction.

None of these justifications for accepting nolo pleas over the Government's objection is satisfactory. The consistent practice of accepting nolo pleas requires that we inquire further into the courts' motivations.

One possible explanation may be found in the views of some commentators who have observed that some trial courts harbor an attitude of "definite hostility" toward the treble damage action. ${ }^{85}$ 'This attitude can be traced to the belief that triple damages by private litigants is a drastic, extraordinary remedy that should be restricted. ${ }^{80}$ Two ele-

85. See Statement of Lee Loevinger, Hearings on the Role of Private Antitrust Enforcement in Protecting Small Business Before a Subcommittee of the Senate Select Committee on Small Business, 85th Cong., 2d Sess., 12 (1958): "In interpretation of law and requirements of proof, the courts are considerably more rigorous when the suit is brought by a private individual than when they are brought by the Government." See also, Statement of Jerrold G. Van Cise, Hearings on H.R. 4597 Before a Subcommittee of the House Committee on the Judiciary, 83d Cong., 1st Sess. 26-27 (1954); Bicks, The Department of Justice and Private Treble Damage Actions, 4 Antrreust Bull. 13-14 (1959); W. HAMtLToN \& I. Trll, ANTITRUST IN Action, 83 (TNEC Monograph 16, 1940): "In general the courts have looked upon suits for triple damages with such disfavor that the statutory presump. tion in favor of the plaintiff is rather lightly entertained and the rebuttal rather gen. erally indulged."

86. The right which the said Acts give to a person to recover three-fold the damages he has sustained, is an unusual one, the remedy is drastic, and the Acts arc to be strictly construed and not to be enlarged by construction.

Westor Theatres v. Warner Bros. Pictures, 41 F. Supp. 757, 762 (D.N.J. 1941); sce also Allgair v. Glenmore Distilleries Co., 91 F. Supp. 93, 97 (S.D.N.Y. 1950): "The extraordinary remedy of triple damages... requires the closest scrutiny of the transaction which is the subject of suit. ..." This attitude may have been manifested in the limitations placed on recovery through the rigorous standards of pleading and proof that have becn imposed on private litigants. In former practice, courts were able to regulate treble damage actions by a stringent requirement of proof of damages that barred as "speculative" any inferential allegation of injury. See Comment, Antitrust Enforcement by Private Parties: Analysis of Developments in the Treble Damage Suit, 61 YALE L.J. 1010, 1025 n.96 and accompanying text (1952). The courts also held the plaintiffs to a strict requircment of direct causal relation between the alleged violation and his loss of business. Id. at 1017 n.46 and accompanying text. The courts have exercised strict control over the treble damage action in yet another way. The plaintiff must show that his claim "is affected with [an] invasion of the public interest." Admiral Theatre Corp. v. Paramount Film Distrib. Corp., 140 F. Supp. 686, 699 (D. Neb. 1955). Thus the plaintiff cannot recover unless he satisfies the court that there has not only been a violation and he has sustained damages but also that "public rights have also been violated." Id. at 695 . The record of plaintiffs' victories in private actions has also been cited as evidence of judicial hostility. Despite the great liberalization in the rules of pleading, discovery, and proof of damages, and despite 
ments probably contribute to the characterization of treble damage relief as drastic. Because of uncertainty and fluctuations in the practices forbidden by the antitrust laws, some courts may feel that exposing antitrust defendants to treble damage liability constitutes a punishment greater than the violation deserves. ${ }^{87}$ And some may feel that punishment should be imposed by courts alone in a fixed and determinable amount. At least one court has given weight to these considerations:

When this Court imposes the penalties they are definite. If, however, treble damages should be recovered, the overall result might be more severe than this Court considered the defendants deserved. If the spectre of treble damage suits is eliminated, the Court can impose the exact punishment that this Court deems appropriate. ${ }^{88}$

In addition to the belief that the treble damage penalty is unduly harsh, other reasons may explain judicial hostility to private suits. The potential windfall of treble damages probably induces some plaintiffs to initiate sham suits. These plaintiffs rely on the fact of a Government conviction alone to press for a settlement of some sort. Other private actions may be the result of competitive antagonism or the last swing of a failing company. Some commentators have pointed to a class of lawyers who specialize in promoting such claims. ${ }^{63}$ The defendants' response is delay-to exhaust the plaintiffs' resources and thereby force the least expensive settlement or abandonment of the litigation. ${ }^{90}$ In the meantime, the courts would have to bear the burden of dilatory motions from plaintiffs as well as defendants. If a private

congressional solicitude towards private antitrust actions, plaintiffs won only 20 of the 144 treble damage actions litigated from 1952 to 1958 . Biclis, stipra note 85 , at 11 . For a slightly higher estimate see Testimony of Victor Hansen, Hearings on the Role of Privote Enforcement, supra note 84, at 129. During the same period the Government won 31 and lost 39 cases after trial. Bicks, supra at 12. On the other hand, plaintiffs suing solely for injunctive relief won 8 out of 17 cases, a record of almost $50 \%$ victory as compared to the $14 \%$ in damage actions. Id. at 11 .

87. See Statement of Hammond E. Chaffetz, Hearings on H.R. 4597, supra note 85, at 16.

88. United States v. Milk Distrib. Ass'n, Crim. No. 25658 (D. MId. 1962), Transcript of Proceedings 2 (February 12, 1962).

89. See Comment, supra note 86 , at 1062 n.335.

90. For some colorful anecdotes of abuse and delay in antitrust litigation sce Statement of Walton Hamilton, Hearings Before the Subcommittec on Study of Monopoly Poues of the House Committee on the Judiciary, 81st Cong., 1st Sess. 285 (1949). According to Hamilton, techniques of delay "have been elaborated into a fine art, and that fine art is now very well established." Id. at 291. See also Comment, Tactical Use and Abuse of Depositions Under the Federal Rules, 59 YALE L.J. 117 (1949). 
action does go to trial a court will be faced with the complex issues usually involved in very time-consuming antitrust proceedings. In addition, a court may be compelled to work with juries that, as a result of plaintiffs' peremptory challenges, lack the sophistication and learning necessary to understand the technical evidence normally adduced by antitrust defendants to disprove involvement in illegal activity. Some courts may feel that such juries tend to return irrational verdicts. It is not surprising, therefore, that antitrust actions may be "a burden, if not a bore, to a busy, overworked court." 01 The possible reasons suggested may have prompted the observation of one prominent judge, Charles E. Clark, who noted "a developing trend in some of our trial courts of hostility toward the 'big' antitrust case and of discovering obstacles-going even back to matters of pleading and pre-trialin the way of a free showing of the need of remedial relief." 02 If these observations are valid, there is reason to believe that the judicial antipathy towards antitrust actions coupled with hostility towards treble damages may result in the use of the nolo contendere plea as a means of escaping the trial of criminal antitrust suits and also the civil suits which might follow a judgment that may be discouraged by the absence of a judgment for the Government entered after trial.

The preceding analysis of the administration of the nolo plea by the Government and the courts illustrates the lack of rational and consistently applied standards. There appear to be considerations beneath the surface which determine how the Government and the courts act in this area. The record also seems to show no continuous commitment to the Sherman and Clayton Acts' conception of the private plaintiff as a coordinate agent for antitrust enforcement. If the litigated cases are a reliable indicator, the Government and the courts have not helped the private party very much. The record of nolo administration, however, has not escaped congressional attention, and measures have been introduced which would alter prior practice.

\section{Congressional Proposals}

In 1963 Congressman Celler observed that it had become "commonplace for the courts to override the Government's objections and accept nolo pleas," 93 and he introduced a bill ${ }^{94}$ designed to stop the practice.

\footnotetext{
91. Eagle Lion Studios, Inc. v. Loew's, Inc., 248 F.2d 488, 451 (2d Cir. 1957) (Clark, J., dissenting).

92. Ibid.

93. 109 CoNG. REc. 16,049 (1963).

94. H.R. 8253, 88th Cong., 1st Sess. (1963), reproduced at 109 CovG. REc. 16,050 (1963) and discussed in Comment, 39 N.Y.U.L. REv. 518 (1964).
} 
His bill would amend the proviso to Section 5 by adding to it: "The term 'consent judgments' as used herein shall not include judgments of conviction based... upon a plea of nolo contendere which has been accepted over the objection of the United States." 05 By giving private litigants the benefit of a judgment entered after a contested nolo plea was accepted, Celler's approach would allow the Government, regardless of the attitudes of courts, to assist private suitors. Whether his amendment would improve the position of private litigants would depend upon the Government's policy regarding opposition to nolo pleas and the courts' reaction in subsequent treble damage actions. Celler appears not to have accounted for these considerations.

A more recent Congressional response was provoked by the Government's position in the steel cases. ${ }^{06}$ Senator Hart introduced a bill ${ }^{07}$ which would make all judgments entered upon nolo pleas, even when the Government does not protest, prima facie evidence against the defendants in subsequent private actions. Hart's bill thus echoes Celler's criticism of the courts but, unlike Celler's bill, would make it impossible for the Government to control the operation of the proviso.

Both proposals properly express a concern over the judicial administration of nolo pleas. And they also share a desire to strengthen the role of private litigants in antitrust enforcement. But both are hasty responses that do not account for all the relevant considerations which may underlie the problem. Before Congress acts in this area, there are some fundamental questions that should be explored. Assuming that Congress wants to continue to use private enforcement it must first determine the efficacy of the private litigants' role under present conditions. Although the statistics of litigated cases ${ }^{98}$ suggest

95. 109 CoNG. REc. 16,050 (1963). Celler's proposal would also exempt guilty pleas from the operation of the proviso, thus codifying the decisions of the courts that have so held. See cases cited note 11 supra.

96. See 111 Conc. REc. 22,516-17 (daily ed. Sept. 9, 1965) (remarks of Senator Hart).

97. S. 2512, 89th Cong., Ist Sess. (1965). The pertinent section of the Fart bill provides as follows:

A final judgment ... rendered in a civil or criminal procceding brought by . . the United States, under any provision of the antitrust laws other than section $4 \mathrm{~A}$ of this Act, to the effect that a defendant has violated said provision shall be-

(2) prima facie evidence against such defendant in any action or proceeding brought by any other party against such defendant under said laws ... if such final judgment or decree was entered before the commencement of the taking of testimony in a criminal proceeding.

The first part of the bill would give judgments conclusive effect if entered after trial.

98. See note 86 supra. 
that private litigants are not very effective, these statistics may not be an accurate gauge. The statistics on litigated cases may represent only a fraction of the total private antitrust activity. They do not encompass the number of cases which are settled out of court before or after the commencement of the suit. A proper index of the success of private enforcement, therefore, must consider whether the bulk of plaintiffs with bona fide claims redress their injuries by adequate settlements out of court. It may be that strong cases against defendants are settled out of court, and only the weak cases are litigated. This practice would explain the poor record of private parties in litigated cases.

If, however, the major portion of private enforcement is represented by litigated cases, the focus of inquiry should be on the full range of explanations for the prior administration of pleas. Some of the factors which motivate decisions in this area may not be known fully even to the courts and the Government. But Congress must learn the reasons for the past performance if it is to legislate intelligently. A solution for each possible reason should be considered. If, for example, the courts' distaste for treble damages is a substantial handicap to the plaintiff, ${ }^{99}$ treble damages might be replaced by an action for actual damages. ${ }^{100} \mathrm{~A}$ greater opportunity to win actual damages might induce as

99. See Statement of Jerrold G. Van Cise, Hearings on H.R. 4597, supra note 85, at 26:

[O]ne of the greatest handicaps, if not the greatest, of a plaintiff in a trcblc-damage action is the treble-damage part of the litigation. . . .

Much of the difficulties experienced over the years by plaintiffs in these actions is believed to stem from a reluctance of juror and judge to make punitive trebled awards in doubtful cases.

100. The suggestion of eliminating mandatory treble damages has been made bcforc. See, e.g., H.R. 4597, 83d Cong., 1st Sess. (1954), which would leave the amount of recovery, not to exceed trebled recovery, to the discretion of the court. Hearing on H.R. 4597 Before a Subcommittee of the House Committee on the Judiciary, 83d Cong., 1st Sess. (1954). This proposal was adopted by the Attorney General's National Committce to Study the Antitrust Laws, which reported:

On balance, we favor vesting in the trial judge discretion to impose double or treble damages. In all instances, this would recompense injured parties. Beyond compensa. tion, the trial court could then penalize the purposeful violator without imposing the harsh penalty of multiple damage on innocent actors.

ATt'y Gen. NAT'L CoMm. ANTITRUST REP. 379 (1955). But the proposal has been criticized as unrealistic, for it is improbable that many courts would resort to doubling or trebling damages. See McConnell, The Treble Damage Issue: A Strong Dissent, 50 Nw. U.L. REv. 342,343 (1955). The basis of this proposal is a fairness consideration which would relicve unwitting offenders from the harshness of treble damage liability. The idea of climinating the treble damage remedy in order to achieve realistic participation by private partics in antitrust enforcement has not been explored.

Again assuming that the litigated cases represent a fair index of private antitrust activity, it could be argued that historically the retention of the bounty part of the private 
many private litigants to sue ${ }^{101}$ and might be feared as much by the defendants as suits for treble damages which plaintiffs seldom win. The penalty aspect of the treble damage action could be replaced by real-

action is not justified. The private litigant was envisioned in the Sherman Act as an independent enforcer who was to uncover antitrust violations and arrest the offenders. Treble damage recovery was the reward for undertaking the task. When in 1914 Congress acknowledged that what had been expected of the private litigant was unreal, it attempted to lessen his burden by permitting him the use of the Government's investigation efforts. However, by linking the private action to the Government's anterior proceedings, Congress did nothing for the concept of private enforcement as initially visualized. Congress again overlooked that what the private litigant needed to perform a true enforecment function was the machinery that would enable him to procure the information necessary to build a solid case. Instead, Congress in effect did two things: it recognized that the real enforcement task of uncovering and arresting the offenders would have to be discharged by the Government, and, by providing an additional inducement for injured parties to sue after the Government's action, it made it casicr for more private litiganes to deliver the punishing blows for which they had been armed by the Sherman Ace. Hence, Congress only reinforced the punishment aspect of the private action. In view of the low penalty provided for violation of the Sherman Act, punishment supplemental to that imposed at the prosecution by the Government was essential. To accomplish that purpose, however, the club with which the private police force had previously been armed for other purposes may have proved somewhat heavier than necessary. If the private action following the Government's proceedings served only to compound the punishment that would make violation unrewarding, that punishment may more fairly and more cffectively be achieved by less than trebled recovery by scores of private litigants.

The immediate objections that would be raised to elimination of triple damages are that without the attraction of an additional bounty fewer injured parties will be enticed into initiating damage suits and that the private action would be stripped of its detcrrence. However, it is probable that as many suits for actual damage would be prompted by a further relaxation on the restrictions on recovery as by the prospect of the additional damages. If more plaintiffs have a real opportunity for recovery, it is probable that the potential violator will fear the private action no less because it is for actual damages. The staggering costs of defending a private action, one of the principal concerns of the antitrust defendant, would be just as high whether the suit is for actual or treble damages. The potential increase in defense costs resulting from a greater number of suits litigated might itself serve as a deterrent. And added to the defendants' liability would be the costs and attorneys' fees of the successful plaintiffs who, encouraged by the prospect of easier victory, might proceed with the litigation undeterred by settlement pressures from the defendants.

101. The prospect of recovering treble damages was never by itself successful in in. ducing the private antitrust plaintiff into litigation. Even the additional assistance extended to the private litigant by the Clayton Act was not a significant stimulant to pri. vate litigants. The combined inducement of triple damages and a judgment admissible against the defendant as prima facie evidence produced only 129 private antitrust suits between 1914 and 1940. See Atr'y GeN. Nat'l Comar. Antrrsust Rer., supra note 100, at

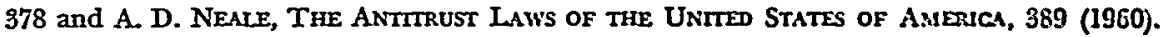
Underlying this sluggish record was the disheartening number of plaintiffs' victories reported after litigation-only 9. Ibid. By contrast, 1186 private antitrust actions were commenced in the eleven year period from 1942 to 1952. Adasinistsative OfFice of U.S. COURTS, ANN. REP. (1942-1952). Several factors other than a treble damage reward may be cited to account for this sudden outburst of private activity. The procedural reform 
istic sanctions in the criminal proceeding. ${ }^{102}$ The possible effect of an actual damages remedy on settlement must also be explored. The burden imposed on judicial machinery by antitrust litigation could be met by measures realistically designed to expedite disposition of these cases. ${ }^{103}$ Similarly, Congress could consider providing for "blue ribbon" juries capable of understanding complex antitrust issues; or juries might be eliminated altogether in civil antitrust actions. Congress should also examine the degree to which private parties have difficulty in proving an antitrust violation even with the evidentiary aid granted by Section 5 . Although Section 5 is generally regarded as a benefit to private parties, in view of judicial attitudes its full value may not always be realized. ${ }^{104}$ Congress could provide instead, as proposed in the

reached a peak in 1938 when the promulgation of the Federal Rules of Civil Procedure relaxed requirements of pleading and eased preparation for trial by offering unprecedented opportunities for discovery by deposition, interrogatories, documents and atdmis. sions. And with the Supreme Court's expansion of the compass of the commerce clausc, the plaintiff was considerably relieved of the added burden of proving the issuc of effects on commerce, a requirement that had frequently served as a barrier to recovery. Also important in facilitating victory for the private suitor was the Supreme Court's decision in Bigelow v. RKO Radio Pictures, 327 U.S. 251 (1946). In that case the Court relaxcd the standards of proof for both causation and damages in the private antitrust action. Possibly the most significant cause of the sudden animation of the private litigant was the Government's energetic role in antitrust enforcement in the post-war period. The prosecutions of the movie industry were probably the most significant stimulant to private actions during that period. See United States v. Paramount Pictures, Inc., 66 F. Supp. 323 (S.D.N.Y. 1946), 70 F. Supp. 53 (S.D.N.Y. 1947), modified and remanded, 334 U.S. 131 (1948), 85 F. Supp. 881 (S.D.N.Y. 1949). Each of the factors cited played an important role not only in facilitating litigation by private plaintiffs but also, more significantly, in instilling confidence of success.

102. Following the electrical industry cases in 1960 several proposals were made to strengthen the penalties for violation of the antitrust laws. S. 2252, 87th Cong., 1st Sess. (1962) proposed to increase the Sherman Act penalties from $\$ 50,000$ to $\$ 100,000$. Upon a second conviction within ten years of the first the fine would be up to $\$ 500,000$ for corporate defendants and up to $\$ 100,000$ plus up to one year in prison for individuals. S. 2254, 87th Cong., 1st Sess. (1962) would expand the liability of corporate directors from $\$ 5,000$ to $\$ 100,000$ and, upon a second conviction, a mandatory imprisonment of up to one year. S. 996, 87th Cong., 1st Sess. (1962), would allow the Attorney General to obtain an orler to restrain individuals and corporations convicted of antitrust violations from rendering any further services to each other. See Hearings Pursuant to $S$. Res. 52 Before the Sub. committee on Antitrust and Monopoly of the Senate Committee on the Judiciary, 87th Cong., 1st Sess. (1962). See also Comment, Increasing Community Control Over Corporale Crime-A Problem in the Law of Sanctions, 71 YALE L.J. 280 (1961), recommending a system. of proportional fines designed to deprive the violator of the profits made by the illegal practices.

103. A recent proposal designed for this purpose would amend the Antitrust Expediting Act, 56 Stat. 198 (1903), 15 U.S.C. $\S 28$ (1964), so as to provide for a national pancl of antitrust judges. H.R. 6766, 87th Cong., Ist Sess. (1961).

104. Section 5 , in and of itself, means little to a plaintiff unless he fortifies its im. pact upon the minds of the jury with a dramatic reproduction, de novo, of the same 
Hart bill, a conclusive effect for Government judgments. ${ }^{105}$ Or it could allow the private plaintiff to rely on the Government judgment to make out his case and impose the burden of disproving guilt by a preponderance of the evidence on the defendant. Perhaps an equally useful approach to facilitating the plaintiff's case would be to give him access to the investigation records, proofs, and other evidence used by the Government to convict the defendant. Whatever may be the merit of these suggestions after full examination, they serve to illustrate that there are many hidden facets to the current problem. If there is any substance to the speculation about why the courts and the Government administer the nolo plea the way they do, Congress would err in assuming that the role of the private litigant could be enlarged simply by repealing the current proviso.

Another preliminary inquiry that Congress should make before enacting legislation regarding the nolo plea is into the desirability of limiting or expanding the Government's control over whether the nolo plea is accepted. A decision on this question involves the answer to two other questions. How much control should the Government have over the amount of private enforcement that may follow a Government proceeding? And, how much control should the Government have over which of its own cases go to trial? The nolo plea allows the Government a half-way prosecution. With it, the Government can reprimand a defendant without exposing him to the full stigma of crim-

kind of evidence which resulted in the Government's earlier victory. . . . Section 5 substantially decreases neither the length of treble damage suits, the extent of trial preparation nor the cost. .."

Communication to Yale Law Journal cited in Note, Clayton Act, Section 5: Aid to Treble Damage Suitors, 61 YALE L.J. 417, 425, n.33 (1952).

As a practical matter, the use of a criminal judgment to prove the existence of a public conspiracy is of very little value. . . [It is] usually desirable to introduce proof of the public conspiracy outside of the criminal judgement."

Ibid. See also HaxiltoN \& TrL, supra note 85. But see Testimony of Jerrold G. Van Cise, Hearings on H.R. 7905 Before the Subcommillee on Sludy of Monopoly Pouter of the House Committee on the Judiciary, 81st Cong., 2d Sess. 52 (1950).

105. The original Section 5 of the Clayton Act as passed by the House provided a conclusive effect for Government judgments. Doubts as to its constitutionality led the Senate to substitute the prima facie evidence provision in its place. See 51 Coxc. REc. 13,851 (1914) (remarks of Senator Walsh); SEN. REp. No. 698, 63d Cong., 2d Sess. 45 (1914). And see generally 4 WIGMore, Evidexce $\S 1353$ (1940). The constitutional challenge is based on the claim that the provision would deny due process to the defendants by denying them a full defense in the private action. But the claim is unfounded, since the defendants would have all the guarantees of due process in the Government proceeding. with rights of appeal to correct any errors. And the scope of application of the Government judgment would still be subject to judicial control. Other attempts have been made to enact the conclusive effect provision. See, e.g., H.R. 7905, 81st Cong., 2d Sess. (19j0); S. 2512, 89th Cong., lst Sess. (1965). 
inality and without increasing his exposure to treble damage liability. A defendant is much more likely to accept this kind of reprimand without a trial than he is a reprimand which precedes numerous treble damage suits. Under the current law, the Government can attempt half-way prosecutions by not contesting acceptance of the plea.

Congressman Celler's proposal would give the Government total discretion to use these half-way prosecutions. This solution may be proper if the Government's allocation of its scant antitrust resources is a significant consideration in its position on nolo pleas and if there are in. deed cases which should be resolved short of full prosecution. Senator Hart's bill, however, would limit the Government's prosecutorial flexibility. The bill would remove the most important inducement that the Government can give to the defendant-immunity from Section 5 . Without this inducement the Government will have much less control over which cases go to trial. The defendant might nevertheless decide to avoid the expense of trial and the possible stigma of a conviction and might therefore plead nolo contendere. But a decision to press for acquittal is equally possible since only acquittal would insure against sub. sequent treble damage actions. In either event under Hart's bill there is little the Government can offer to induce the defendant to forego trial.

Another element of prosecutorial discretion is affected by the Congressional proposals. Although the Government has not stated that its past failures to contest nolo pleas involved considerations of the fairness of subjecting certain defendants to greater treble damage liability, it is arguable that this factor has entered into prosecutorial decisions. The Hart proposal seems to assume that such considerations should not be entrusted to the Government and also that weight should not be given to any other considerations which might have prompted the Government to accept less than full prosecution. The assumption underlying the Hart proposal may be correct. Perhaps the Government should not have the discretion to protect certain defendants from the stigma of criminality and potential treble damage liability. Whether the Government should have some control over the form and degree of prosecution and punishment cannot, however, be answered without knowing the Government's view and the motivating elements in its prior decisions not to contest nolo contendere pleas. This information should be brought before the Hart Committee and must be considered. 